\title{
Service Quality Dimension of E-Banking Services - A Study With Reference to Vellore District
}

\author{
Dr. K. Aruna \\ Assistant Professor, Auxilium College (Autonomies), Vellore, Tamil Nadu
}

\begin{abstract}
"Investment banking is not a business; it is a personal service where bankers work hand in hand with their clients. It is a service that must not simply be about making bigger and bigger deals that reap rewards for only a small group of executives".
\end{abstract}

- Felix Rohatyn

\begin{abstract}
The development of Information Technology has seen a big boom in the banking industry. With Ebanking, the bricks and mortar structure of the traditional banking gets converted into click and portal model, thereby giving the concept of E-banking a real shape. Thus, today's banking is no longer confined to the branches. Customers are being provided with additional delivery channels which are more convenient to customers and are cost effective to the banks. The researcher has identified that the other researchers have carried on their research and given suggestions based on Parasuraman Zeithml model, which is a traditional one. Banking has undergone many innovations due to technology up gradation. The Cronbach's Alpha Criterion was applied to test the reliability. the alpha scores on reliability, responsibility, tangibility, assurance, empathy, efficiency, fulfillment and privacy are significantly higher than 0.75. This indicates items used for mentioned services quality dimensions are highly reliable. Hence, the researcher has found this to be the gap. Along with the traditional model SERVQUAL, the E-QUAL Model has been combined in this research work.
\end{abstract}

Keywords: E-banking, Servqual, E-Qual , Customers

\section{INTRODUCTION}

The new distribution channel for banking is Electronic banking. Banks will have trans-national customers which enable the banks to earn more foreign exchange. Electronic banking offers its products and services through ATMs, Mobile banking, Internet banking, Tele-Banking, Core banking service, etc. Online banking helps consumers to overcome the limitations of place and time as they can bank anywhere and anytime as these services are available 24 hours, 365 days a year without any physical limitations of space like a specific bank branch, city or region. They also bypass the paper based aspect of traditional banking.

\section{IMPORTANCE OF E-BANKING}

Electronic distribution channels provide alternatives for faster delivery of banking services to a wider range of customers. (Kaleem and Ahmed 2008). Most of the customers who begin banking online do it because they need to pay bills frequently and would like to do it with minimum effort. Besides that, people use the electronic banking to keep an eye on their money matters, view their account balance and check security payments from other parties. (Kolodinsky JM Hogarth and Hilgert. MA, 2004). Information technology allow electronic channels to do many banking function that would traditionally be carried out over the counter (Giannakoudi 1999,) the use of paper cheques has been supplemented step by step with E-cheques (electronic images) allowing banks to have more storage capacity, reduce costs, and improve customer services.(Rose and Hudgins 2005).

E-banking offer enormous benefits to consumers in terms of the ease and cost of transactions. Online banking helps banks to retain their existing customers, improve customer satisfaction, increase banks' market share, reduce administrative and operational cost and more importantly improve banks' competitive position (Khalfan. et al, 2006). (Liao et al, 63-74) electronic banking is in many ways similar to traditional payment methods. This is a vital difference with traditional system that allows customers to have access to information and its banking operations and transactions do regardless of the location and use of personal computers and software and electronic communications networks.

\section{STATEMENT OF THE PROBLEM}

The researcher has enlisted all the essential features of the E-banking value added services individually, such as ATM, Mobile banking, Credit / Debit card, Internet banking and telephone banking. The responses extracted are based on the awareness of the customers on the usage of such services. The previous researchers have not given much emphasis on 


\section{International Advanced Research Journal in Science, Engineering and Technology}

Vol. 5, Issue 11, November 2018

each and every individual value added service. The researcher has identified that the other researchers have carried on their research and given suggestions based on Parasuraman Zeithml model, which is a traditional one. Banking has undergone many innovations due to technology up gradation. Hence, the researcher has found this to be the gap. Along with the traditional model SERVQUAL, the E-QUAL Model has been combined in this research work.

\section{OBJECTIVES OF THE STUDY}

1. To study the social, economic profile of E-banking customers and the details of E-banking.

2. To identify the service quality dimension of E-banking services and to check their reliability and validity.

3. To find the influence of the demographic profile of the customers on the perception towards service quality dimension of E-banking services.

\section{REVIEW OF LITERATURE}

This chapter is designed to give a detailed review of previous research conducted relating to E-banking services from journals, research articles and reports

Demographic factors have also been found to be related to adoption of different banking channels, especially internet banking by Al-Ashban and Burney, (2001); Karjaluoto et al, (2002); Sathye, (1999). For instance, people with high educational attainment may have ability for computers and possess good information processing skills. Further, customers belong to upper middle class and have high-level occupations are more likely to use Internet banking. Shergill and Li's (2005) depicted that women are more serious regarding the security issues compared to their male counterpart.

Khorana (2009) depict that age has a significant impact on the operational efficiency of clients. As regards reliability, customers had no trust in websites. Akinci et al.'s (2004) findings in Turkey show that mid-aged customers are more likely than younger or older customers to use internet banking.

Maiyaki and Mokhtas (2010) shown in their research that there is no relation between population statistics and choice of banks. It was also found that statistically there is a significant relationship between age and choice of banks. Fozia, (2013) had determined the customer's perception toward the E-banking services. Different age group of customers and different occupation group of customers had a different perception towards e-banking services.

According to Poona, (2008), age, education level, computer skills and internet access at home/office were significantly related to the usage of E-banking services. Shaun and Shanmugham (2003) did not found significant impact of age and education in the use of E-banking, whereas significant impact was found to have the monthly income. In the study of Nasri (2011) resulted that education level and profession were significant factors impacting the acceptance of Internet banking by the clients, whereas age and gender were not significant.

Friedman et al, (2000). Privacy is a significant dimension that may affect users' objective to adopt E-based transaction systems. Encryption technology is the most frequent feature at all bank sites to secure information privacy, supplemented with a mixture of different unique identifiers. Grouping of smart card and biometric recognition using fingerprints offers a more secure and easier access control for computers than the password method. Zeithaml et al (2000) developed E-SERVQUAL for measuring.

E-Rec S-QUAL scale which consists of three dimensions with eleven attributes, including responsiveness, compensation, and makes contact with (Parasuraman, Zeithaml, \& Malhotra, 2005). Various other researchers used, customized versions of E-service quality dimensions Santos 2003; Yang \& Fang, 2004; Jun \& Cai, (2001) to measure these dimensions in different types of retail settings.

Four core dimensions of E-S-QUAL scale are efficiency, fulfillment, system availability, and privacy. Efficiency defines the customers' capability to access the website, find their preferred product and related information, and check it out with least effort. Fulfillment refers to a company's actual performance in contrast with what is promised through the website and incorporates accurateness of service promises, such as having products in stock and timely delivery of services. System availability is a technical function of the website, such as the extent to which it is available and functioning properly. Finally, privacy refers to the company's ability to maintain the integrity of customer data (Zeithaml, Parasuraman, \& Malhotra, 2005).

Jayawardhena (2004) determined that customers highlight the consequence of downloading speed, navigability, and look for prospect efficiency. The study concluded that banks should center on building trust through ensuring the security and privacy of customer information.

Hossein Ganjinia, Shahram Gilaninia, Taher Kouchaki Tajani (2013) the study was to scrutinize the impact of online service quality on customer satisfaction in banks of Guilan. Six factors including reliability, responsiveness, competence, efficiency, privacy and Product portfolio were identified as dimensions of online service quality. E-service quality dimensions had a direct association with customer satisfaction and allowed financial institutions to develop and execute appropriate marketing strategies. 


\title{
International Advanced Research Journal in Science, Engineering and Technology
}

\author{
Vol. 5, Issue 11, November 2018
}

The researcher has chosen to adapt the E-S-QUAL and E-Rec S-QUAL models established by Parasuraman et al. (2005). These are known models are generic and parsimonious scales. The modification was introduced to better suit the purpose of the research; the researcher added efficiency and fulfillment dimensions to the models above and dropped one dimension of system availability from the E-Rec S-QUAL scale.

Liao and Cheung (2005) present a user-based core framework for evaluating service quality of E-banking. Empirical results suggest that apparent usefulness, ease of use, speed of login and logoff, prompt replay, security and privacy and constant improvement of E-banking services significantly influence customer attitudes towards E-banking.

Customer Satisfaction has a positive impact on customer fulfillment in E-banking. The more satisfaction, the more fulfillment will be attained. The Customer Value and privacy had the greatest impact on satisfaction. Mohammad Nazaripour (2013).

Wolfinbarger and Gilly (2002) through interviews with the focus group and an online survey recognized four dimensions for online retail service quality: website design, reliability, privacy and customer services. The study originates that reliability and customer services have the strongest predictors in service quality dimensions.

Demyana Nathan, (2014) There are eight key dimensions of E-service quality, including efficiency, fulfillment, system availability, privacy, assurance/trust, site aesthetics, responsiveness, and contact, which control overall Ebanking service quality with regard to customer relationship and satisfaction. The strongest predictor was the fulfillment attributes, which has a positive and significant relationship with overall E-banking service quality.

People-based Service especially banking company must focus on all the dimensions in SERVQUAL to improve customers' perceptions of service quality. Therefore, it would be useful if E-banking customers are categorized into various segments based on individual E-S-QUAL score. Mass Hareeza Ali (2012).

There is a strong and positive correlation between E-S-QUAL and E-Rec S-QUAL scales and the overall perception of banking websites. The dimension that yielded the highest impact was "Contact" followed by "Responsiveness". Dimitris Paschaloudis, (2014). The most important factors that influence the customer satisfaction are Responsiveness and reliability on the bank's website. Sunayna Khurana (2009). Customers were satisfied with quality of service on four dimensions such as reliability, accessibility, Privacy/security, responsiveness, and fulfillment, but least satisfied with the 'user-friendliness' dimension. Mohammed Sadique Khan and Siba Sankar Mahapatra (2009).

Fatemeh Sakhaei S., Ahmad J., Afshari, Ezzatollah Esmaili, (2014) the study showed that the reliability, efficiency, responsiveness, fulfillment, security/privacy and website dimensions have a meaningful relationship with customer satisfaction in E-banking. The results indicated that the reliability index was the most efficient and website design was the least effective on customer satisfaction than other indicators.

Jayawardhena (2004) determined that customers highlight the importance of privacy, fulfillment easy navigation, and look for feature efficiency. The study concluded that banks should center on building trust through ensuring the security and privacy of customer information. In the context of online banking services, exploratory research done in the context of online retailing by Jun, Yang, and Kim, (2004) revealed that reliable, attentive, and ease of use had considerable impacts on both customers' perceived overall service quality and satisfaction. It also indicated that there is a significant positive relationship between overall service quality and satisfaction.

From the above reviews on E-service quality, many authors has founded various factors depending upon the country, technological development, customer profile and usage. From this background it may be understood that there is no tailor made format for Electronic service quality, since it changes with time and requirement. Therefore, the researcher has taken the factors such as Efficiency, Fulfillment and Privacy in addition to the traditional factors.

\section{DEMOGRAPHIC PROFILE OF THE E - BANKING CUSTOMERS in VELLORE DISTRICT}

The Demographic profile plays a very important role in determining the customer's satisfaction in availing banking service. The financial institutions mainly focus on the demographic profile which helps them to ascertain the customer preferences, type of services required and other service quality demands. After reviewing national and international literature the researcher has taken Gender, Age, Educational Qualification, Occupation, Monthly Income of the Family, Ownership of banks, Mode of awareness, Frequency of using E-banking services is considered to describe the sample unit.

Table No.4.1Gender of Respondent

\begin{tabular}{|l|l|l|l|l|}
\hline & Gender & Frequency & Percent & Valid Percent \\
\hline \multirow{4}{*}{ GENDER } & Male & 278 & 53.9 & 53.9 \\
\cline { 2 - 5 } AGE & Female & 238 & 46.1 & 46.1 \\
\cline { 2 - 5 } & $15-25$ & 119 & 23.1 & 23.1 \\
\cline { 2 - 5 } & $25-35$ & 135 & 26.2 & 26.2 \\
\cline { 2 - 5 } & $35-45$ & 128 & 24.8 & 24.8 \\
\cline { 2 - 5 } & $45-65$ & 134 & 26.0 & 26.0 \\
\hline Education & HSC & 138 & 26.7 & 26.7 \\
\hline
\end{tabular}




\section{International Advanced Research Journal in Science, Engineering and Technology}

Vol. 5, Issue 11, November 2018

\begin{tabular}{|c|c|c|c|c|}
\hline \multirow{4}{*}{ qualification } & Undergraduate & 159 & 30.8 & 30.8 \\
\hline & Postgraduate & 108 & 20.9 & 20.9 \\
\hline & Professional course & 108 & 20.9 & 20.9 \\
\hline & Others & 3 & 0.6 & 0.6 \\
\hline \multirow{4}{*}{ Occupation } & Students & 72 & 14.0 & 14.0 \\
\hline & Professional & 188 & 36.4 & 36.4 \\
\hline & Business men & 104 & 20.2 & 20.2 \\
\hline & Agriculture and others & 152 & 29.5 & 29.5 \\
\hline \multirow[t]{4}{*}{ Income } & Below 10,000 & 137 & 26.6 & 26.6 \\
\hline & $10,000-20,000$ & 105 & 20.3 & 20.3 \\
\hline & $20,000-30,000$ & 139 & 26.9 & 26.9 \\
\hline & Above 30,000 & 135 & 26.2 & 26.2 \\
\hline \multirow{3}{*}{$\begin{array}{l}\text { Ownership of } \\
\text { banks }\end{array}$} & Public sector & 201 & 39.0 & 39.0 \\
\hline & Private sector & 205 & 39.7 & 39.7 \\
\hline & Foreign banks & 110 & 21.3 & 21.3 \\
\hline \multirow{5}{*}{$\begin{array}{ll}\text { Mode } & \text { of } \\
\text { awareness } & \end{array}$} & Newspapers/Magazine & 119 & 23.1 & 23.1 \\
\hline & Bank officials & 180 & 34.9 & 34.9 \\
\hline & Television/Media & 76 & 14.7 & 14.7 \\
\hline & Friends & 127 & 24.6 & 24.6 \\
\hline & Relatives & 14 & 2.7 & 2.7 \\
\hline
\end{tabular}

Source: Primary data

The sample unit comprises 53.9\% of male banking customers. 26.2\% are between the age group of 25-35 years. Maximum number of $36.4 \%$ are postgraduate and professional further 20,000 -30,000 income groups are using Ebanking services. $39.7 \%$ are private sector bank customers. it is found that $34.9 \%$ of customers are recommended by bank officials to use E-banking services.

1.4.1 Service Quality Dimension of E-Banking Services and to check their Reliability and Validity- Factor Analysis

The researcher considered 23 service quality elements in Licker 5 point scale, which varies from strongly agree, agree, not sure, disagree and strongly disagree. The main aim of the researcher is to ascertain the existence of service quality elements out of 23 variables based on Parasuram Zeith model; therefore 23 variables are subject to factors analysis by principle component method to derive the number of meaningful factors. The results of factor analysis on 23 variables are presented below:

Table 4.14 Factor analysis for influencing service quality dimension

\begin{tabular}{|l|l|l|}
\hline Service Quality & Initial & Extraction \\
\hline Information about transactions that is provided by the bank is accurate & 1.000 & .779 \\
\hline The bank website is functioning properly & 1.000 & .702 \\
\hline Information content and text are easy to read and understand & 1.000 & .837 \\
\hline The bank is willing to help customers, provide prompt service and information & 1.000 & .737 \\
\hline Immediate confirmation is provided in the bank website & 1.000 & .751 \\
\hline $\begin{array}{l}\text { The bank handles problems promptly and compensates for any kind of loss due to } \\
\text { wrong transactions }\end{array}$ & 1.000 & .863 \\
\hline Modern equipment & 1.000 & .795 \\
\hline Bank employees are appealing & 1.000 & .795 \\
\hline $\begin{array}{l}\text { Material associated with the services such as plastic credit card or bank statement is } \\
\text { visually attractive }\end{array}$ & 1.000 & .773 \\
\hline Services offered by the bank are trustworthy & 1.000 & .976 \\
\hline The bank has got good reputation & 1.000 & .974 \\
\hline Bank employees are polite to customers & 1.000 & .976 \\
\hline Banks provide individual attention & 1.000 & .977 \\
\hline Banks gives convenient operating hours to all customers & 1.000 & .983 \\
\hline Banks understand specific needs of their customers & 1.000 & .964 \\
\hline The bank website is simple to use & 1.000 & .980 \\
\hline
\end{tabular}




\section{International Advanced Research Journal in Science, Engineering and Technology}

Vol. 5, Issue 11, November 2018

\begin{tabular}{|l|l|l|}
\hline The bank website is accessible throughout the day & 1.000 & .948 \\
\hline The speed of login or sign-off is fast & 1.000 & .962 \\
\hline The bank's site provides a confirmation of the required services quickly & 1.000 & .935 \\
\hline The bank's site provides a confirmation of the required services quickly & 1.000 & .921 \\
\hline The bank confidentially collects and maintains personal information of customers & 1.000 & .918 \\
\hline Banks do not disseminate customer information to third parties & 1.000 & .893 \\
\hline The bank website is completely secure for credit card information & 1.000 & .983 \\
\hline
\end{tabular}

Extraction Method: Principal Component Analysis

From the table 4.14 , it is inferred that the 23 variables possess the variable which ranges from .600 to .982 . It implies that 23 variables exhibit the variances from $60 \%$ to $98 \%$ which is statistically significant at $5 \%$ level. This indicates that 23 variable can be converted into meaningful factors. The following total variance table indicates the number of factors derived out of 23 variables.

Table 4.15 Factor analysis for influencing service quality dimension - Total Variance Explained

\begin{tabular}{|c|c|c|c|c|c|c|c|c|c|}
\hline \multirow[t]{2}{*}{ Component } & \multicolumn{3}{|c|}{ Initial Eigenvalues } & \multicolumn{6}{|c|}{$\begin{array}{l}\begin{array}{l}\text { Extraction Sums of Squared Rotation Sums of Squared } \\
\text { Loadings }\end{array} \\
\text { Loadings }\end{array}$} \\
\hline & Total & $\%$ of Variance & Cum \% & Total & $\%$ of Variance & Cum \% & Total & $\%$ of Variance & Cum \% \\
\hline 1 & 7.543 & 32.794 & 32.794 & 7.543 & 32.794 & 32.794 & 6.915 & \begin{tabular}{|l|l}
30.064 & 3
\end{tabular} & 30.064 \\
\hline 2 & 4.113 & 17.884 & 50.679 & 4.113 & 17.884 & 50.679 & 3.738 & 16.251 & 46.314 \\
\hline 3 & 2.266 & 9.853 & 60.532 & 2.266 & 9.853 & 60.532 & 2.257 & 9.815 & 56.129 \\
\hline 4 & 2.131 & 9.265 & 69.797 & 2.131 & 9.265 & 69.797 & 2.041 & 8.872 & 65.001 \\
\hline 5 & 1.473 & 6.404 & 76.201 & 1.473 & 6.404 & 76.201 & 2.012 & 8.746 & 73.747 \\
\hline 6 & 1.271 & 5.524 & 81.725 & 1.271 & 5.524 & 81.725 & 1.336 & 5.810 & 79.557 \\
\hline 7 & .938 & 4.080 & 85.804 & .938 & 4.080 & 85.804 & 1.182 & 5.139 & 84.696 \\
\hline 8 & .688 & 2.991 & 88.795 & 688 & 2.991 & 88.795 & .943 & 4.099 & 88.795 \\
\hline 9 & .641 & 2.787 & 91.582 & & & & & & \\
\hline 10 & .527 & 2.293 & 93.875 & & & & & & \\
\hline 11 & .451 & 1.963 & 95.838 & & & & & & \\
\hline 12 & .302 & 1.313 & 97.150 & & & & & & \\
\hline 13 & .229 & .996 & 98.146 & & & & & & \\
\hline 14 & .146 & .636 & 98.782 & & & & & & \\
\hline 15 & .097 & .421 & 99.203 & & & & & & \\
\hline 16 & .076 & .331 & 99.534 & & & & & & \\
\hline 17 & .057 & .246 & 99.780 & & & & & & \\
\hline 18 & .025 & .107 & 99.888 & & & & & & \\
\hline 19 & .015 & .063 & 99.951 & & & & & & \\
\hline 20 & .007 & .032 & 99.983 & & & & & & \\
\hline 21 & .003 & .015 & 99.998 & & & & & & \\
\hline 22 & .001 & .002 & 100.000 & & & & & & \\
\hline 23 & -1.090 & -4.737 & 100.000 & & & & & & \\
\hline
\end{tabular}

Extraction Method: Principal Component Analysis.

From the table it is found that 23 variables explain a total variance of $88.795 \%$ they are converted into 8 preponderate factors with individual variances of $30.064 \%, 16.251 \%, 9.815 \%, 8.872 \%, 8.764 \%, 5.810 \%, 5.139 \%$ and $4.099 \%$. After confirming the eight factors of service quality dimensions the researcher obtains following grouping of variables

From the above table it is found that the first factor consists of

F11 - Information content and text are easy to read and understand (.765)

F21 - Information about transactions that is provided by the bank is accurate (.752)

F-13-The bank website is functioning properly (.600)

Therefore, this factor is known as "Reliability". The website information is easy to read and understand by the customers and it functions effectively. The accurate and reliable information provided in the bank website paves way for reliability. Hence it can be a dimension to measure the banking service quality.

From the table it is indicated that the second factor consists of

F8- Immediate confirmation is provided on the bank website (.809).

F9-The bank is willing to help customers, provide prompt service and information (.781).

F20-The bank handles problems promptly and compensates for any kind of loss due to wrong transactions (.771). 


\section{International Advanced Research Journal in Science, Engineering and Technology}

Vol. 5, Issue 11, November 2018

Therefore, this factor is known as "responsiveness". The banks provide prompt services and give confirmation to the customers relating to various transactions done through E-banking and compensate for the financial loss due to wrong transactions. This is one of the key quality determinants of service quality that is important to customer satisfaction.

From the above table it denotes that the third factor consists of

F22-Bank employees are appealing (.837).

F10-Material associated with the services such as plastic credit card or bank statement is visually attractive (.776).

F12-Bank has modern equipments (.734).

Therefore, this factor is known as "tangibility". Another important factor which influences the customers to avail Ebanking services is tangibility of the banks. It has a positive power on physical facilities, equipment and looks of personnel. Without appealing personnel, well-equipped infrastructure, customers will not have the inclination to use the services provided by financial institutions.

From the above table it is found that the fourth factor consists of

F1-Bank employees are polite to customers (.982).

F18-Services offered by the bank is trustworthy (.981).

F19-Bank has got good reputation (.973).

Therefore, this factor is known as "assurance". Another important factor which influences the customers to avail Ebanking services is assured. Customers expect bank employees to be polite, trustworthy and banks have good reputation. Thus, this factor of assurance determines customer satisfaction.

From the above table it is found that the fifth factor consists of

F2-Banks provide individual attention (.981).

F2-Banks gives convenient operating hours to all customers (.980).

F4-Banks understand the specific needs of their customers (.973).

Therefore, this factor is known as "empathy". Excellent banks will have convenient operating hours, individual attention and banks understand the specific needs of their customers. Only when there is empathy rather than sympathy, the customers also will prefer such banks.

From the above table it is found that the sixth factor consists of

F6-The speed of login or sign-off is fast (.974).

F5-The bank website is simple to use (.983).

F23-The bank website is accessible throughout the day (.889).

Therefore, this factor is known as "Efficiency". Reputed banks will provide websites which are simple to use, having speedy login and signing off and is accessible throughout the day. The accurate and reliable information provided in the bank website paves way for Efficiency. Hence it can be a dimension to measure the banking service quality.

From the above table it is found that the seventh factor consists of

F14-The bank's site fulfills the service request at the first instance (.920).

F15-The bank's site provides a confirmation of the required services quickly (.915).

Therefore, this factor is known as "fulfillment". Excellent banks will fulfill service requests at the first instance and give confirmation of the required service quickly. This creates a greater impact on customer satisfaction. A fulfilled customer will be a satisfied customer.

From the above table it is found that the "eight factors" consists of

F3-The bank website is completely secure for credit card information (.980).

F16-The bank confidentially collects and maintains personal information of customers (.880).

F-17Banks do not disseminate customer information to third parties (.874).

Therefore, this factor is known as "privacy". Popular banks will have a website which is completely secure, confidentially maintains personal information and does not disseminate information to third parties. Hence customers prefer banks, which can maintain privacy to others.

\section{Hypotheses Testing - 1}

"There is a significant difference among the factors of service quality dimensions of E- banking service". From the above table it is found that eight factors have different variances therefore the hypothesis is rejected at $5 \%$ level and concluded that there is no significant difference among the factors of service quality dimensions of E- banking service.

\section{A model of service quality of E-banking services and Customer satisfaction}

After reviewing Parasuraman, A., Zeithaml, V., and Berry, L. Model of service quality researcher conjectured the existence of eight service quality factors such as reliability, responsiveness, tangibility, assurance, empathy, efficiency, fulfillment, privacy and its respective relationship with customer satisfaction. 


\section{International Advanced Research Journal in Science, Engineering and Technology}

Vol. 5, Issue 11, November 2018

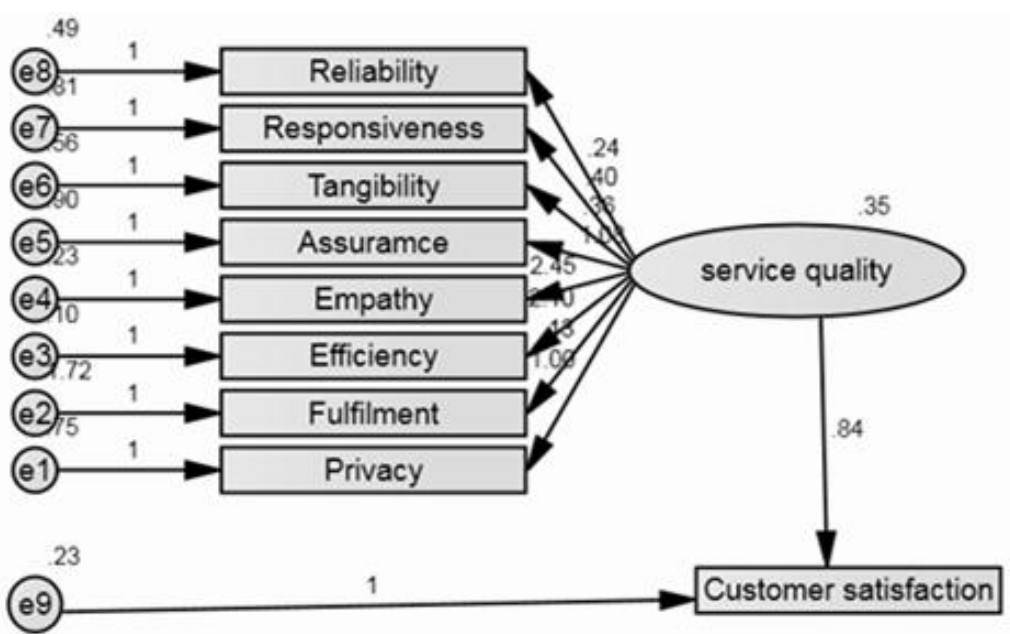

Figure $-5.1 \mathrm{Model}$ of service quality of E-banking services and Customer satisfaction

In order to prove this conjecturer through model fit, the researcher exploited structural equation model and the above mentioned diagrammatic model is obtained. The model indicates the eight factors of service quality are confirmed to explain the effective service quality of E-banking services. Subsequently the relationship with customer satisfaction is also well-defined and proved empirically.

\subsection{FINDINGS}

The social Economic profile presents the gender, age, educational qualification, occupation, income, ownership of banks, awareness level, mode of awareness and its services of ATM, mobile banking, credit card, telephone banking and internet banking and service quality dimensions are given below.

* Of the total E-banking customers maximum of $53.9 \%$ are male and $46.1 \%$ are female customers. Age is an important aspect to ascertain the customers' needs in E-banking services. $26.2 \%$ of majority is with the age group of 25 35 years and the least, $23.1 \%$ are between the age group of $15-25$ years.

* In education levels maximum of $30.8 \%$ are undergraduates and $20.9 \%$ are post graduates and professional customers. With reference to occupation, $36.4 \%$ are professionals followed by $29.5 \%$ are agriculture and other category. * Out of the total $26.9 \%$ of the respondents fall under the category of income earning 20,000 $-30,000$ and $26.6 \%$ are below 10,000 of income levels per month. Maximum of 39.7\% of private sector bank customers, 39\% of public sector and $21.3 \%$ foreign bank customers avail E-banking services in Vellore.

* In mode of awareness majority of $34.9 \%$ of customers are recommended by Bank officials to use E-banking services and the least $2.7 \%$ are influenced by relatives.

* The 23 variables explain a total variance of $88.795 \%$ they are converted into 8 predominate factors Reliability, Responsiveness, tangibility, Assurance, Empathy, Efficiency, Fulfillment and Privacy.

\section{CONCLUSION}

Information technology has played a vital role in the advancement of the banking system. Customer's satisfaction can be well measured by service quality dimensions of reliability, responsiveness, tangibility, assurance; empathy, fulfillment, efficiency and privacy have proved to be essential to all sections, types and cadres of the customer. Each dimension has a special relevance to every customer. A combination of the dimensions can create delighted, rather than just satisfied customers. With the advance of technology, enhancement of knowledge and broader exposure to the internet may lead to many more dimensions to measure service quality. With the dwindled world, whatever dimension is available at the international level very easy may influence the domestic customers.

\section{REFERENCES}

[1]. Akinci, S., Aksoy, S. and Atilgan, E. (2004). Adoption of internet banking among sophisticated consumer segments in an advanced developing country, International Journal of Bank Marketing, Vol. 22 No. 3, pp. 212-32.

[2]. Al-Ashban, A.A., and Burney, M.A. (2001). Customer adoption of tele-banking technology: the case of Saudi Arabia., Vol. 19 No. 5, pp. $191-200$.

[3]. Demyana Nathan, (2014). The Relationship Among E-service Quality Dimensions, Overall Internet Banking Service Quality and Customer Satisfaction in the USA, Journal of Modern Accounting and Auditing, ISSN 1548-6583, Vol. 10, No. 4, pp. $479-493$.

[4]. FatemehSakhaei.S., Ahmad J. Afshari, EzzatollahEsmaili , (2014). The Impact of Service Quality on Customer Satisfaction in Internet Banking, Journal of mathematics and computer science 9, PP. 33-40.

[5]. Fozia, (2013). A Comparative Study of Customer Perception toward E-banking Services Provided By Selected Private and public sector banks in India, International Journal of Scientific and Research Publications, Vol. 3, Issue 9, ISSN 2250-3153. 


\section{International Advanced Research Journal in Science, Engineering and Technology}

Vol. 5, Issue 11, November 2018

[6]. Fozia, (2015). Determinants of Customers Perception Of E-Banking Services in North India: An Analysis, International Journal of Research in Economics and Social Sciences.

[7]. Friedman, B., Kahn, P.H. Jr, and Howe, D.C. (2000). Trust online. Communications of the ACM, 43, (2),pp. 34-40.

[8]. Hossein VazifehDoost, 1., Azadeh Ashrafi, (2014). Relationship of Online Service Quality with Customer Satisfaction in Internet Banking Case Study: Pasargad Bank, International Journal of Economy, Management and Social Sciences, Vol. 3(1), pp.130-135.

[9]. Jayawardhena, C. (2004). Measurement of service quality in internet delivered services: The development and validation of an instrument. Journal of Marketing Management, 20(1/2), 185-209.

[10]. Jun, M. and Cai, S. (2001), The key determinants of Internet banking service quality: a content analysis, International Journal of bank Marketing, Vol. 19, No. 7, pp.276-291.

[11]. Karjaluoto, H., Mattila, M., and Pento, T. (2002). Factors underlying attitude formation towards online banking in Finland. International Journal of Bank Marketing, 20(6), pp.261 - 272

[12]. Khorana , (2009). Grounded Theory: I mentioned it once but I think I got away with it. Paper presented at the Information Systems-The Next Generation. Proceedings of the 4 th UKAIS Conference. York UK. pp.129-141.

[13]. Liao and Cheung, (2005). Service Quality in Internet E-Banking: A User-Based Core Framework. E -Technology, E-Commerce and E -Service, International Conference on E- Technology, E-Commerce and E -Service, Vol. 5, pp. 628-631.

[14]. Maiyaki A and MohdMokhtas, S.S., (2010), Effects of Electronic Banking Facilities, Employment Sector and Age Group on Customers, Choice of Banks in Nigeria , Journal of Internet Banking and Commerce, Vol. 15, No. 1, pp. 1-8.

[15]. Mohamed A.I. and Mohammed A.Y.O., (2012): Factors influencing the Adoption of E-banking in Sudan: Perceptions of Retail Banking Clients, Journal of Internet Banking and Commerce. Vol. 17, pp.3-7.

[16]. Nasri W., (2011). Factors influencing the adoption of internet banking in Tunisia. International Journal of Business and Management, Vol. 6(8),

[17]. Parasuraman, A., Berry, L. L. and Zeithaml, V. A., (1988). Communication and control processes in the delivery of service quality, Journal of Marketing, Vol. 52, April, pp.35-48.

[18]. Parasuraman, A., Zeithaml, V. A., and Berry, L. L. (1998). SERVQUAL: A Multiple-Item Scale for Measuring Consumer Perceptions. Journal of Marketing, Vol. 72, April, pp.14-24.

[19]. Parasuraman, A., Zeithaml, V.A., Malhotra, A.,(2005). E-S-Qual: a multiple item scale for measuring electronic service quality. Journal of Service Research 7 (3), 213-233.

[20]. Poona, (2008). An Empirical Study - Awareness of Customers on Service Quality of Public Sector Banks in Varanasi,Journal of Business Management and Social Sciences Research , ISSN No: 2319-5614 Vol. 2, No.1

[21]. Santos, J., (2003). E-service quality: a model of virtual service quality dimensions, Managing Service Quality, Vol. 13, No.3, pp. 233-246.

[22]. Sathye, M., (2008), Adoption of Internet-banking by Australian Customers: An Empirical Investigation, International Journal of Bank Marketing, Vol. 17, No.17, pp.324-34.

[23]. Shakeri, A., (2007). Study of Factors Vital to Implement E-banking in Iran Successfully. M. A. dissertation of Tehran University of Iran.

[24]. Wolfinbarger, M.F. and Gilly, M.C. (2002), ComQ: Dimesionalizing, Measuring and Predicting Quality of the E-tail Experience, Working paper, Marketing science Institute, Cambridge, M.A., 01-100.

[25]. Yavas, U., Bilgin, Z., \&Shemwel, D. J., (1997). Service quality in the banking sector in an emerging economy: a consumer survey. International Journal of Bank Marketing, 15(6), pp.217-223.

[26]. Yang, Z. and Jun, M., (2002). Consumer perception of E-service quality: from internet purchaser and non-purchaser perspectives. Journal of Business Strategies, Vol. 19 (1), 19-41. 